Conclusion The raised levels of VEGF in SLE might be related to the process of endothelial repair present in different organs of lupus patients.

\section{OP0009 SLE-RELATED T CELL AUTOIMMUNITY TO HISTONES AND NUCLEOSOMES IS AN INHERENT PROPERTY OF THE NORMAL IMMUNE SYSTEM}

KA Fenton, M Van Ghelue, OP Rekvig. Biochemical, University of Tromsoe, Tromsoe, Norway

\subsection{6/annrheumdis-2001.1234}

Background Systemic lupus erythematosus (SLE) is characterised by the generation of pathogenic $\mathrm{B}$ cell and $\mathrm{T}$ cell autoimmunity to DNA and nucleosomes. Human polyomavirus T-antigen may play a central role in initiating $\mathrm{B}$ cell and $\mathrm{T}$ cell autoimmunity to nucleosomes. Recent data demonstrate that nucleosome-T-antigen complexes stimulate nucleosome-specific B cells and T-antigen specific $\mathrm{T}$ cells through a hapten-carrier-like process, also indirectly resulting in termination of non-responsiveness of histone-specific $\mathrm{T}$ cells. This process is relevant to both SLE and normal individuals.

Objectives This work focuses on whether immune (T-antigen specific) and autoimmune (histone-specific) $T$ cells from normal individuals share functional, structural and genetic characteristics with those deriving from SLE.

Methods Histone-specific T cell clones were generated by stimulation of peripheral blood mononuclear cells with nucleosome-Tantigen complexes and subsequently maintained by pure histones. T-antigen specific $\mathrm{T}$ cell clones were initiated and maintained by polyomavirus T-antigen. The frequencies of circulating $\mathrm{T}$ cells specific for these antigens were determined in healthy individuals and SLE patients by limiting dilution of blood mononuclear cells. $T$ cell receptor gene usage and structure of their variable regions were determined by cDNA sequencing. The sequences were compared between the $\mathrm{T}$ cell populations, and between normal and SLE subjects for both T-antigen and histone specificity.

Results The frequencies of circulating T-antigen- or histone-specific $\mathrm{T}$ cells in normal individuals were similar to those of SLE patients. Some of the histone-specific $\mathrm{T}$ cells, derived from normal individuals, were clonally expanded, indicating that these cells are functionally activated in vivo in healthy individuals. Although heterogeneous for variable region structure and gene usage, histone specific $\mathrm{T}$ cells from healthy individuals and SLE patients selected glutamic and/or aspartic acids at position 99 and 100 of the $\mathrm{Vb}-\mathrm{CDR} 3$.

Conclusion Autoimmune T cells induced among peripheral blood mononuclear cells from normal individuals were highly similar to those from SLE, demonstrating that $\mathrm{T}$ cell autoimmunity to nucleosomes is an inherent property of the normal immune system.

\section{REFERENCES}

1 Andreassen K, Bredholt G, Moens U, Bendiksen S, Kauric G, Rekvig OP. Eur J Immunol. 1999;29:2715-28

2 Andreassen K, Moens U, Nossent H, Marion TN, Rekvig OP. Arthritis Rheum. 1999:42:2449-60

3 Moens U, Seternes OM, Hey AW, Silsand Y, Traavik T, Johansen B, Rekvig OP. Proc Natl Acad Sci USA 1995;92:12393-7

4 Moens U, Seternes OM, Johansen B, Rekvig OP. Virus Genes 1997;15:135-54

5 Rekvig OP, Andreassen K, Moens U. Scand I Rheumatol. 1998;27:1-6

6 Rekvig OP, Fredriksen K, Hokland K, Moens U, Traavik T, Krishnan MR, Marion T. Scand I Immunol. 1995;41:593-602
7 Rekvig OP, Moens U, Sundsfjord A, Bredholt G, Osei A, Haaheim H, Traavik T, Arnesen E, Haga HJ. J Clin Invest. 1997;99:2045-54

\section{OP0071 A PATHOGENIC ANTI-DNA ANTIBODY BINDS TO ALPHA- ACTININ IN RENAL MESANGIAL CELLS}

C Putterman, B Deocharan. Division of Rheumatology, Albert Einstein College of Medicine, Bronx, NY, USA

10.1136/annrheumdis-2001.1235

Background Anti-DNA antibodies have been demonstrated to play an important role in the pathogenesis of nephritis in systemic lupus erythematosus. One mechanism by which anti-DNA antibodies may contribute to nephritis is by cross-reactivity with renal antigens. However, the identity of this renal antigen remains elusive.

Objectives To identify the target antigen bound by a pathogenic anti-DNA antibody in renal tissue.

Methods Western blotting and immunoprecipitations of total cell lysate from mesangial cell lines derived from the autoimmune MRL-lpr/lpr mouse (lpr-mc) and a non-autoimmune BALB/c mouse (mc), with R4A, a pathogenic murine IgG2b anti-DNA antibody, and with 95, a non-pathogenic antibody derived from R4A by site-directed mutagenesis. The immunoprecipitated protein was identified by matrix assisted laser desorption ionisation mass spectrometry (MALDI-MS) of tryptic digests.

Results The pathogenic anti-DNA antibody R4A, but not control isotype-matched antibodies, bound to and immunoprecipitated a $100 \mathrm{kD}$ protein from mesangial cell lysates. Binding was more pronounced using lpr-mc rather than non-autoimmune mc lysate. Little effect on binding was seen after treatment of the cell lysate or R4A with DNAse, while proteinase $\mathrm{K}$ treatment abolished binding. Preliminary MALDI-MS analysis revealed that alphaactinin, an actin bundling protein that plays a role in experimental nephritis models, is present in the protein band immunoprecipitated by R4A. R4A, but not 95, binds to immobilised alphaactinin by ELISA; Furthermore, double stranded DNA significantly inhibited the binding of R4A to the $100 \mathrm{kD}$ mesangial cell protein, as well as to purified alpha-actinin. Serum of MRL-lpr/ lpr lupus mice with active disease contain high-titer antibodies to alpha-actinin.

Conclusion The nephritogenicity of some anti-DNA antibodies may be mediated via cross-reactivity with a glomerular antigen. Variations in the display of the cross-reactive antigen in the target organ between individuals may underlie differential susceptibility to anti-DNA antibody induced renal disease.

\section{OP0072 INCREASED CALRETICULIN EXPRESSION ON SURFACE MEMBRANES OF MONOCYTES AND NEUTROPHILS IN SYSTEMIC LUPUS ERYTHEMATOSUS: RELEVANCE TO APOPTOTIC CELL CLEARANCE}

AP Cairns, AD Crockard, AL Bell. Queen's University Department of Rheumatology, Musgrave Park Hospital, Belfast, UK

\subsection{6/annrheumdis-2001.1236}

Background Increased numbers of apoptotic leukocytes ${ }^{1}$ and impaired clearance of apoptotic cells ${ }^{2}$ have been demonstrated in SLE. Patients with $\mathrm{C} 1 \mathrm{q}$ deficiency almost invariably develop SLE, probably because $\mathrm{C} 1 \mathrm{q}$ is important in the clearance of apoptotic cells by monocyte/macrophages. ${ }^{3}$ Calreticulin has been shown to bind to the early complement component C1q, and 